\title{
Możliwości wykorzystania repozytoriów internetowych typu Cloud w dydaktyce
}

https://doi.org/10.25312/2391-5129.30/2020_061si

\begin{abstract}
W pracy przedstawiono przegląd wybranych repozytoriów danych w technologii tzw. danych Chmury - Data Cloud. Zarysowano ich powstanie i rozwój ze wskazaniem podstawowych zalet i możliwości, szczególnie współdzielenia zasobów pamięci oraz mocy przetwarzania. Wyszczególniono i scharakteryzowano szereg popularnych serwisów Cloud, w tym: OneDrive, Google Drive, Dropbox. Podkreślono przydatność internetowych repozytoriów danych dla wspomagania prowadzenia dydaktyki. Wskazano na możliwość uzupełnienia technicznego platform zdalnego kształcenia oraz użyteczność Data Cloud w przechowywaniu i udostępnianiu prac o dużym zapotrzebowaniu na pamięć masową.
\end{abstract}

Slowa kluczowe: internetowe repozytoria danych, Data Cloud

\section{Wstęp}

Cel artykułu stanowi przegląd oraz wskazanie przydatności wybranych repozytoriów internetowych typu Cloud we wspomaganiu prowadzenia dydaktyki. Zaprezentowano definicje i podstawowe charakterystyki funkcjonalne wybranych repozytoriów, dostępność, popularność wśród użytkowników oraz perspektywy rozwoju. Specyfikę przechowywania i przetwarzania danych masowych w tak zwanej chmurze cechuje elastyczność i wygoda mobilnego dostepu. Technologia Cloud zapewnia nowatorskie podejście w zarządzaniu firmami, kształceniu zdalnym oraz gromadzeniu i udostępnianiu danych przez użytkowników indywidualnych.

* Dr Liwiusz Siemianowski - adiunkt na Wydziale Informatyki i Techniki Akademii Humanistyczno-Ekonomicznej w Łodzi. 


\section{Definicja, model i rozwój technologii Cloud}

Repozytorium internetowe danych typu Cloud stanowi obszar pamięci masowej udostępniany użytkownikowi w sposób usługowy. Repozytorium określane również jako chmura danych - Data Cloud wykształcone zostało z koncepcji chmury obliczeniowej-Cloud Computing.

Celem organizacji repozytoriów Cloud jest zapewnienie elastycznego dostępu do danych masowych z wybranych urządzeń i lokalizacji. Repozytoria internetowe pozwalają na eliminację ograniczeń z powodu oddalenia geograficznego użytkownika od miejsca przechowywania danych.

Korzystanie z repozytoriów zapewniają urządzenia ze stacjonarnym lub bezprzewodowym dostępem do internetu: komputer personalny i przenośny, tablet, smartfon. Model funkcjonalny dostępu do repozytorium danych Cloud - chmury danych zobrazowano na rysunku 1.

Idea przechowywania i przetwarzania danych w repozytorium typu Cloud bazuje na tzw. wirtualizacji zasobów poprzez zastąpienie konieczności posiadania własnych nośników danych ofertą składowania usługowego w pamięci masowej o dużej pojemności z zapewnieniem dostępu zdalnego. Usługi repozytoryjne oferowane są w sposób odplatny lub bezpłatny z pewnymi warunkami, takimi jak zgoda na otrzymywanie reklam - podobnie jak w serwisach poczty elektronicznej.

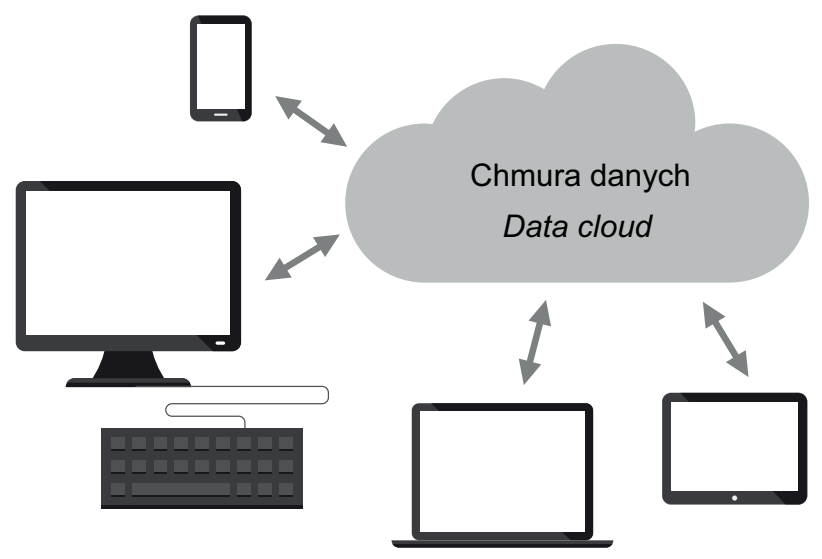

Rysunek 1. Model przechowywania danych w repozytorium internetowym typu Cloud Źródło: opracowanie własne.

Model chmury obliczeniowej wypracowano z koncepcji przetwarzania danych w sieci komputerów integrujących udostępnianie usług i zasobów, tzw. Grid/Utility Computing (przetwarzanie sieciowe/użytecznościowe). Technologicznie stanowi system obejmujący szereg komputerów przetwarzających w sieci dane dla realizacji wyznaczonych zadań. Zapewnia zwielokrotnienie mocy obliczeniowej, zwiększenie efektywności przetwarzania ze skróceniem czasu wykonania zadań. 
Udostępniane zasoby to między innymi:

- moc obliczeniowa z odpowiednią pamięcią operacyjną,

- pamięć masowa,

- przepustowość łączy,

- oprogramowanie (na podstawie określonej licencji).

Model Cloud pozwala ponadto na rozważenie i zaplanowanie aspektu ekonomicznego przetwarzania i utrzymywania danych poprzez określenie kosztów użytkowania systemu lub poszczególnych komponentów: mocy obliczeniowej, wielkości wykorzystywanej pamięci masowej, stosowanych serwisów oprogramowania, wielkości dostępnego pasma komunikacji.

Atutem przetwarzania sieciowego jest zwiększenie niezawodności i możliwość tzw. skalowalności - dostosowania wielkości pamięci lub mocy przetwarzania systemu do potrzeb obiektu ekonomicznego - przedsiębiorstwa, instytucji lub użytkownika indywidualnego.

Zadaniem wyspecjalizowanego repozytorium danych, czyli chmury danych Cloud, jest skoncentrowanie na udostępnianiu zasobów pamięci masowych zoptymalizowanych dla potrzeb usługobiorcy z możliwością zwiększania oraz ewentualną regulowaną odpłatnością.

Dynamika wzrostu wartości rynku usług Cloud wskazuje na zainteresowanie wymienioną technologią wśród firm w Polsce (rys. 2). W sektorze biznesowym udział firm (rys. 3) stosujących technologie Cloud w Polsce w 2018 roku według Eurostatu wynosił około 11,5\% (na podstawie rys. 2 wykresu Eurostatu: isoc_cicce_use). Średni wskaźnik dla Unii Europejskiej wynoszący około $26 \%$ osiąga wartość na podobnym poziomie dla największych krajów Unii jak Niemcy, Francja, Włochy (Eurostat: isoc_cicce_use). W Wielkiej Brytanii, która opuściła Unię, odnotowany przez Eurostat w 2018 roku wskaźnik udziału wynosił ponad 40\%. Przekroczenie 50-procentowego udziału zastosowań technologii Cloud w sektorze firm notują jedynie kraje skandynawskie.

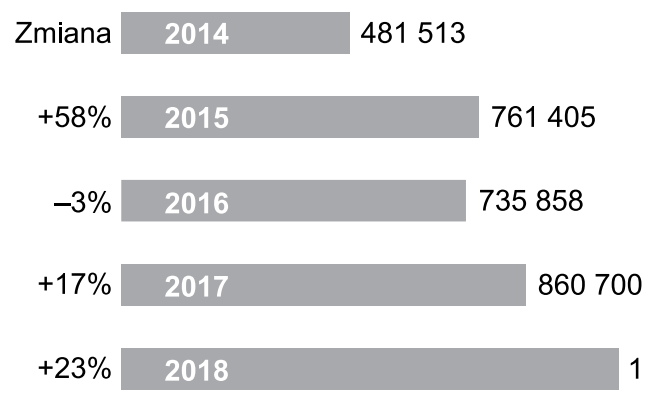

1065328

Rysunek 2. Szacunkowa wartość (w tys. zł) oraz procentowa dynamika wzrostu rynku usług typu Cloud w Polsce w latach 2014-2018

Źródło: Chmura publiczna w Polsce 2019, 2019. 


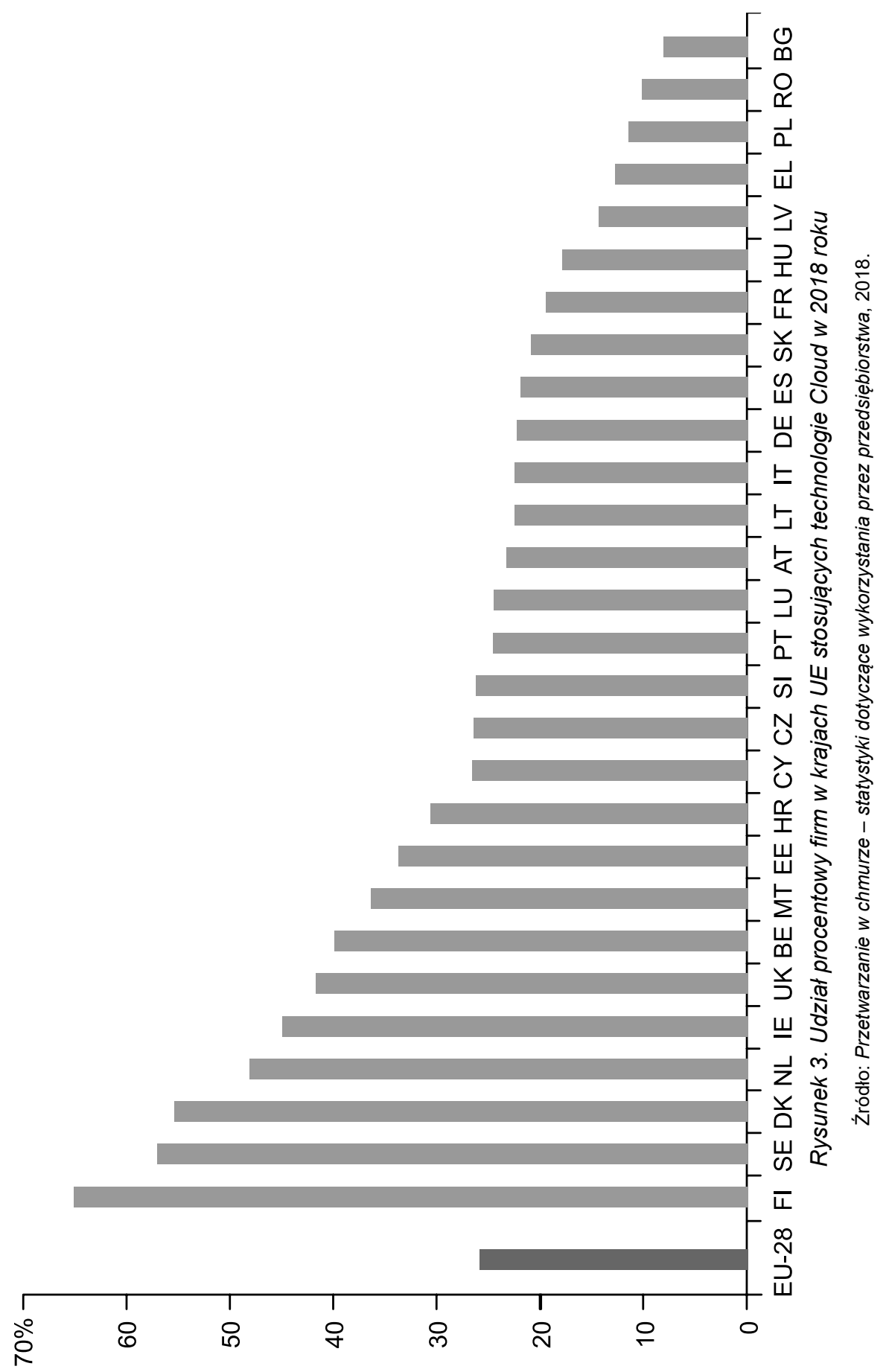


Analiza wymienionych wskaźników pozwala na wysunięcie tezy, że technologia Cloud nadal stanowi nowość w dziedzinie wspomagania zarządzania i należy spodziewać się dalszego dynamicznego wzrostu jej zastosowań.

W przypadku użytkowników indywidualnych wydaje się, że rozpowszechnienie informacji dotyczących funkcjonalności repozytoriów również wpłynie na wzmożone wykorzystanie usług typu Cloud.

\section{Charakterystyka typologiczna wybranych repozytoriów Cloud}

Możliwe jest wyróżnienie - przy zastosowaniu umownego kryterium przynależności podstawowych typów repozytoriów Cloud - chmur danych firmowych oraz publicznych.

Chmury prywatne - firmowe (ang. private cloud) stanowią autonomiczne komponenty przynależne określonej instytucji, świadczące wewnętrzne usługi dla obiektu ekonomicznego. Utrzymywane i zarządzane są zwykle przez departament informatyczny przedsiębiorstwa posiadającego własną serwerownię i osobny personel. Alternatywnie realizowane są $w$ formie outsourcingu, tj. obsługi przez firmę zewnętrzną. Chmury firmowe predestynowane są dla dużych obiektów ekonomicznych: przedsiębiorstw, instytucji, urzędów itp.

Repozytoria w postaci chmury publicznej (ang. public cloud) stanowią ofertę usługi ogólnodostępnej dla odbiorców indywidualnych zarówno biznesowych, jak i osób fizycznych. Realizowaniem usług repozytoryjnych Cloud zajmują się między innymi renomowane firmy Google, Microsoft, Apple i inne (rys. 4).
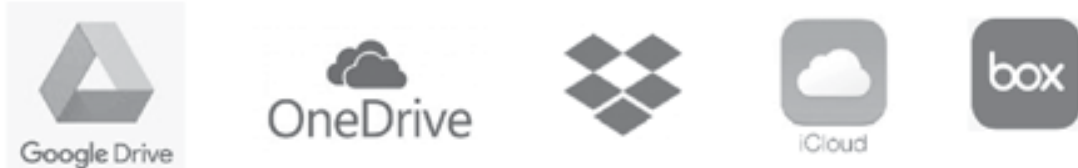

Rysunek 4. Emblematy wybranych internetowych serwisów repozytoriów danych: Google Drive, MS OneDrive, DropBox, Apple iCloud oraz Box

Źródło: opracowanie własne na podstawie stron WWW.

W przypadku chmury publicznej wskazać można na podział na usługi komercyjne oraz nieodpłatne o zmniejszonej funkcjonalności. Popularne repozytorium Cloud stanowi dysk sieciowy Google Drive (rys. 5) oferowany przez serwis internetowy Google, znany szczególnie z narzędzi komunikacyjnych - poczty elektronicznej oraz serwisu Web informacji geograficznej Google Maps. Ułatwienie stanowi możliwość synchronizacji zarządzania plikami przechowywanymi przez użytkownika w serwisach Google, na przykład poczty. Repozytorium Google Drive wyposażono w moduł Google Photos do archiwizacji zdjęć o rozdzielczości do 12 megapikseli. Wyjściowa 
wielkość oferowanego bezpłatnie obszaru wynosi 15 GB. Maksymalna pojemność w wersji odpłatnej osiąga $30 \mathrm{~TB}$. Ułatwione jest wykonywanie kopii zapasowych wybranego przez użytkownika folderu komputera lub karty pamięci aparatu fotograficznego. Serwis Google Drive zapewnia elastyczny dostęp z komputerów i urządzeń przenośnych, tabletu, smartfona.

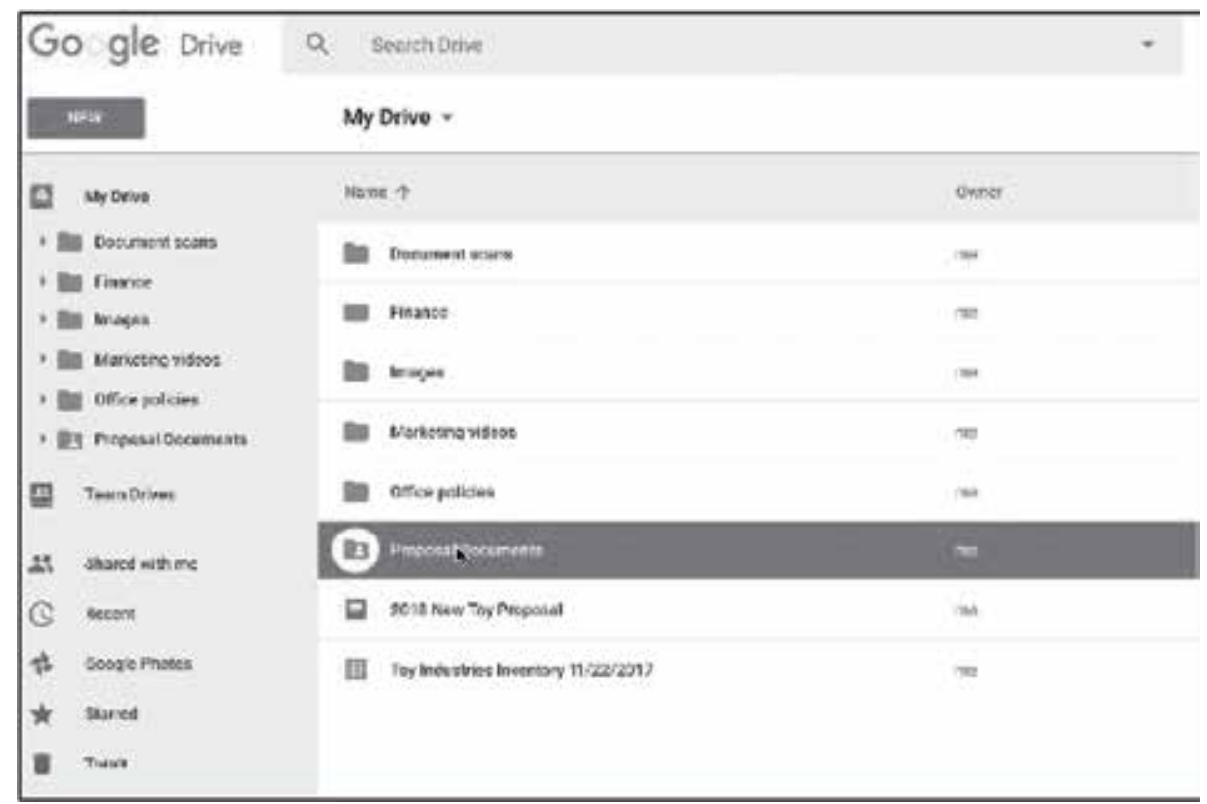

Rysunek 5. Interfejs obsługi repozytorium Google Drive

Źródło: opracowanie własne na podstawie stron WWW serwisu.

Repozytorium OneDrive Cloud oferowane przez firmę Microsoft zapewnia wsparcie producenta popularnego pakietu oprogramowania Office i Windows. Uwidocznione przez wejście do OneDrive w opcjach menu rozwijanego systemu operacyjnego Windows. Serwis OneDrive umożliwia synchronizację urządzeń mobilnych, katalogowanie i udostępnianie plików oraz ułatwioną obsługę plików pakietu MS Office, tj. arkuszy kalkulacyjnych xls/x, dokumentów tekstowych doc/x itd. Wersja premium serwisu OneDrive wymaga wnoszenia opłat w trybie miesięcznym lub rocznym. Oferowany obszar pamięci dyskowej rozpoczyna $5 \mathrm{~GB}$ w wersji nieodpłatnej z ograniczoną funkcjonalnością. W odmianie premium obszar pamięci osiąga do 5 TB.

Repozytorium DropBox stanowi jeden z bardziej popularnych serwisów. Zapewnia wygodne archiwizowanie danych, logowanie $\mathrm{z}$ wybranego miejsca $\mathrm{z}$ wykorzystaniem komputera lub urządzeń mobilnych. Oferuje możliwość zautomatyzowanego przesyłania i zaszyfrowania zdjęć ze smartfona. W odmianie nieodpłatnej serwisu DropBox oferowany obszar pamięci wynosi 2 GB. Wersja biznesowa wymaga 
współdzielenia miejsca dla trzech lub więcej użytkowników. Pojemność wersji biznes osiąga 2 TB lub jest nielimitowana z osobno naliczaną odpłatnością od każdego użytkownika.

Repozytorium iCloud specjalizowane zostało dla komputerów i urządzeń firmy Apple z systemem operacyjnym MacOS. Pozwala na synchronizację dokumentów oraz automatyczne tworzenie kopii zapasowych. Umożliwia minimalizację ryzyka utraty danych na przykład w przypadku zagubienia sprzętu. Pozwala na udostępnianie i współdzielenie zasobów z wybranymi użytkownikami. Obszar pamięci w repozytorium iCloud wynosi od 5 GB do 2 TB.

Serwis repozytorium Cloud Box o funkcjonalności zbliżonej do poprzednich cechuje ułatwiona obsługa dokumentów z pakietu MS Office 365. Dostępne bezpłatnie miejsce obejmuje 10 GB pamięci dyskowej. Pojemność 100 GB oferowana jest za odpłatnością dla użytkowników indywidualnych. Podobnie opłat wymaga uzyskanie pamięci masowej bez ograniczenia dla użytkowników biznesowych. Zestawienia cenników utrzymania obszarów dyskowych publikowane są między innymi w sieci WWW (zob. Opulski, 2018).

We wspomaganiu prowadzenia dydaktyki pomocne wydają się chmury publiczne szczególnie w odmianie bezpłatnej. Zapewniają na przykład uzupełnienie techniczne platform zdalnego kształcenia poprzez przechowywanie i udostępnianie prac o większej zajętości pamięci masowej rzędu giga/terabajtów, jak filmy, animacje, zaawansowane prace graficzne $\mathrm{i}$ fotografie.

\section{Zalety repozytoriów typu Cloud}

Zalety internetowych repozytoriów typu Cloud to:

- elastyczność funkcjonalna; dostęp do danych oferowany jest z dowolnego urządzenia w dowolnym czasie i miejscu;

- skalowalność zasobów pamięci masowej; sukcesywny wzrost zapotrzebowania na zasoby pamięci (np. 5/10/20 GB/TB i więcej) zaspokajany zostaje przez Cloud bez konieczności samodzielnego zwiększania liczby nośników danych;

- możliwość zmniejszenia kosztów poprzez uwolnienie od zakupu i posiadania koniecznych urządzeń pamięci masowej; koszt udostępniania usługi zostaje rozłożony na większą liczbę użytkowników;

- scentralizowane oraz zoptymalizowane zarządzanie danymi; użytkownikowi wystarcza znajomość wielkości (ewentualnie ceny w wersji komercyjnej) oferowanej pamięci bez potrzeby rozpatrywania rodzaju, organizacji, liczby i pojemności nośników danych/dysków, macierzy dyskowych itp.;

- synchronizacja dostępu do plików i zmniejszenie ryzyka zagubienia bądź utraty danych;

- zwiększenie bezpieczeństwa przetrwania zarchiwizowanych w Cloud danych. 
Do ujemnych stron repozytoriów Cloud zalicza się:

- ryzyko komplikacji w przypadku nieosiągalności internetu w żądanym czasie - szczególnie z urządzeń mobilnych, na przykład brak sieci, zasięgu, zakłócenia transmisji z powodu lokalnych warunków propagacji i natężenia sygnału,

- w przypadku chmury obliczeniowej ryzyko opóźnienia w działaniu udostępnianych zdalnie aplikacji - w efekcie brak możliwości pracy w czasie rzeczywistym,

- ryzyko wielogodzinnej lub nawet dłużej trwającej przerwy w dostępie do danych w przypadku poważnej usterki systemu Cloud, jak na przykład awaria Cloudflare w lipcu 2020 roku (Urbaniak, 2020).

\section{Podsumowanie}

Internetowe repozytoria danych Cloud znajdują coraz szersze zastosowanie we wspomaganiu prowadzenia działalności gospodarczej instytucji, przedsiębiorstw oraz aktywności biznesowej mniejszych firm. Istotną, wyróżnioną gałąź zastosowań w gospodarce stanowi edukacja zdalna - e-learning. Edukacja na odległość realizowana przy wykorzystaniu technologii informatycznych jest również wyznacznikiem nowej strategii kształcenia w społeczeństwie informacyjnym. Edukacja zdalna, e-dydaktyka zapewnia studiowanie i doskonalenie umiejętności oraz wybór ośrodka nauki niezależnie od oddalenia geograficznego od miejsca zamieszkiwania.

Specyfika i elastyczność rozwiązań Cloud wskazują na szczególną ich przydatność dla realizacji dydaktyki w procesie edukacji zdalnej.

Podstawowymi zaletami technologii Cloud, między innymi dla dydaktyki, są:

- elastyczność funkcjonalna wynikająca $\mathrm{z}$ dostępu do danych $\mathrm{z}$ wybranego urządzenia bez ograniczenia czasowo-przestrzennego,

- skalowalność pamięci masowej - wzrost zapotrzebowania użytkownika na zasoby pamięci nie wymaga samodzielnego zwiększania liczby nośników danych,

- możliwość zmniejszenia kosztów poprzez brak konieczności zakupu własnych urządzeń pamięci masowej oraz podział kosztu usługi komercyjnego repozytorium Cloud na grupę użytkowników,

- scentralizowane i zoptymalizowane zarządzanie danymi bez konieczności planowania organizacji fizycznej, na przykład katalogów, liczby, rodzaju i pojemności nośników danych,

- synchronizacja dostępu do plików z różnych urządzeń - przenośnych oraz stacjonarnych,

- zmniejszenie ryzyka zagubienia lub utraty danych.

Technologię internetowych repozytoriów danych, tzw. chmury - Data Cloud, cechuje zapewnienie elastycznego dostępu do danych masowych z wybranych urządzeń i lokalizacji - bez ograniczeń z powodu przestrzennego oddalenia użytkownika od miejsca przechowywania danych. Specyficzna właściwość utrzymywania i prze- 
twarzania danych w chmurze z wygodnym dostępem z urządzeń mobilnych zwiększa efektywność zarządzania firmą. Repozytoria Cloud zapewniają rozszerzenie możliwości użytkowników indywidualnych, w tym studentów uczelni, w gromadzeniu i udostępnianiu danych. Internetowe repozytoria wykazują szczególną użyteczność we wspomaganiu prowadzenia dydaktyki. Przykładowo repozytorium Cloud zmniejsza ryzyko zakłócenia toku dydaktyki z powodu zapomnienia przez użytkownika nośnika danych z prezentacją, pracą lub referatem. Repozytoria typu Cloud wykazują ponadto przydatność we wspomaganiu dydaktyki poprzez przechowywanie i udostępnianie prac o większej zajętości pamięci masowej rzędu giga- i terabajtów, takich jak filmy, animacje, zaawansowane prace graficzne, zdjęcia. Repozytoria Cloud zapewniają również możliwość uzupełnienia technicznego platform zdalnego kształcenia.

Wydaje się że w terminie Cloud - chmura udało się zawrzeć podkreślenie łatwości i bliskości przechowywania oraz udostępniania zbiorów danych w repozytoriach internetowych.

Repozytoria Cloud stanowią nadal nowość i można oczekiwać dalszego dynamicznego rozwoju ich wykorzystania między innymi we wspomaganiu procesów dydaktycznych w modelu nauczania zdalnego.

\section{Bibliografia}

Chmura publiczna w Polsce 2019 (2019), Computerworld Top 200.

Kowalski J. (2015), Chmury publiczne - porównanie dostęnych rozwiąań, https:// www.computerworld.pl/news/Chmury-publiczne-porownanie-dostepnych -rozwiazan,400758,5.html [dostęp: 15.06.2020].

Opulski P. (2018), Usługi chmurowe - porównanie ofert, https://publicystyka.ngo.pl/ uslugi-chmurowe-porownanie-ofert [dostęp: 15.04.2020].

Piotrowski M. (2018), Pliki w chmurach, „PC Format”, nr 11.

Przetwarzanie $w$ chmurze - statystyki dotyczace wykorzystania przez przedsiębiorstwa (2018), Eurostat, https://ec.europa.eu/eurostat/statistics-explained/index.php/Cloud computing__ statistics on the use by enterprises [dostęp: 2.11.2020].

Urbaniak P. (2020), Ogromna awaria Cloudflare, https://www.dobreprogramy.pl/ Ogromna-awaria-w-Cloudflare.-Nie-dziala-szereg-uslug-i-serwisow-internetowych,News, 109008.htm [dostęp: 18.07.2020].

\section{Serwisy internetowe $z$ ofertą usług repozytoryjnych:}

Dropbox, www.dropbox.com.

Google Drive, www.google.com. 


\section{Summary}

\section{The possibilities of Cloud repository for didactics}

The internet data repositories of Cloud type are presented. A short review of selected popular Cloud services is discussed. The basic parameters of the volume of massive data memory for commercial and non-profit individual users are noted. The possibilities of Data Cloud services for supporting remote didactics are listed.

The Cloud repository may be especially useful for storing files with large disk memory demands, such as graphical works, films, animations etc.

Keywords: internet data repositories, Data Cloud 